in the usual sense (1507). As many who are conscious of the ironies of history have observed, the Palestinians as refugees suffer from the conditions historically ascribed to the stateless Jews before the creation of modern Israel. The challenge for history is to not repeat and to change, to ask if the only refuges for diasporas are nation-states armed to the teeth and at war with their neighbors.

Rather than portray Gaza as a Troy or Guernica-to what end? - the hope would be to move beyond heroic monumentalization into peacemaking and futures without war. Perhaps Ra'ad is accurate in suggesting that sometimes it appears as if the issue focuses more on war than on resistance movements, although several of the shorter pieces we commissioned discuss resistance, especially in the Latin American context. All the same, it would have been hubristic for a one-time special issue to seek after encyclopedic comprehensiveness with respect to war and resistance, both historical and contemporary.

Despite the literal-mindedness Ra'ad exhibits for most of his letter, he reads his concerns into the cover of the special issue, which features Susan Meiselas's disturbing photograph of three Sandinista guerrilleros in simple wire-mesh masks, youthful Davids fighting authoritarian Goliaths with stones. What better figurative evocation of the Palestinian situation than this photograph of masked stone-throwing youths? If a picture is worth a thousand words, the cover of our special issue evokes conflicts such as the ongoing one in Palestine to all those who may never crack open the journal. If Ra'ad were not caught up in identity politics, he would see the cover as speaking to resistance movements the world over, including the one in Palestine.

Gaza also inverts the gaze. If Milton's Samson promised that he would "Israel from Philistian yoke deliver," Ra'ad expects that PMLA should do the opposite and deliver Gaza from the Israeli yoke. However, as Milton continues, "Ask for this great deliverer now, and find him / Eyeless in Gaza at the mill with slaves." Is literary and cultural criticism expected to save the world? Take sides on every issue? Or analyze complexities that do not always translate into political activism? We are bound to disappoint partisan expectations. Writing words on a page is not dissimilar to grinding grain. How many unsuccessful Samsons blindly dream of bringing down the edifice on their oppressors? We might stay Miltonic by suggesting that as scholars and teachers "[we] also serve who only stand and wait," even if we have not yet managed to end all wars while continuing to read PMLA.

Srinivas Aravamudan

Duke University

\section{What Is Poetry?}

\section{To THE EDITOR:}

As someone who teaches both literary criticism and creative writing, I sympathize with $\mathrm{Si}$ mon Jarvis in his wish for a more rigorous poetics (“For a Poetics of Verse," 125.4 [2010]: 931-35). Reading a poem as a sociopolitical tract or a semantic exercise is valid but often seems to miss the point of the verse qua verse. And anyone teaching poetry recognizes how little readers today know about traditional metrics and rhyme. So it's refreshing to see the old exegetical emphasis on what a poem means supplanted by an emphasis on rhetoric, on how something means. As Susan Sontag once wrote, "In the final analysis, 'style' is art."

Yet Jarvis's desire to privilege prosody runs into a problem of differentiation. Paraphrasing Allen Grossman, he notes approvingly, "Verse adepts cut up, mutilate, select from languageusing intonation contours, rhythms, print, gesture, and so on.... When language has had all this done to it, it is no longer only language." But where is the dividing line between mere language and poetry? Maybe poetry is "a performance in words," as Robert Frost put it, but it's been over half a century since the publication of J. L. Austin's How to Do Things with Words, and by now most critics know how difficult it is to separate constative utterances (which work on the level of simple description) from performative ones (which achieve a degree of art).

David Galef Montclair State University 
Reply:

I thank David Galef for his remarks. Might I make two points in reply? 1 . My essay does not offer to supplant exegesis with an emphasis on rhetoric, but suggests that poetics need not subserve hermeneutics. That is a quite different matter. 2. Galef asks: "where is the dividing line between mere language and poetry?" In my short essay, though, I explained that I had made a deliberate choice to refer not to "poetry" but to "verse." To draw a distinction between performative and constative language may or may not, as Galef believes, be a precondition necessary to the provision of a definition of poetry, but it is not a precondition necessary to the task of specifying verse styles and their histories. I don't yet know what poetry is, and that may indicate why "poetry" is both a more powerful and a more difficult term than "verse." I referred in my essay to what I regard as a good working definition of verse, Derek Attridge's. Whether or not everyone can agree upon that definition, it is not necessary for those interested in the history of verse practice to down tools until such time as a universally approved formula might have been arrived at.

Simon Jarvis University of Cambridge

\section{Humor and Politics}

\section{To THE EDITOR:}

I read with great interest Jean-Jacques Lecercle's article "Return to the Political," which appeared in the special issue on literary criticism for the twenty-first century (125.4 [2010]: 916-19). As a proponent and critic of humor, I had read Lecercle's book Philosophy of Nonsense: The Intuitions of Victorian Nonsense Literature (Routledge, 1994) and wondered what role nonsense would play in his newest propositions. I opened the journal with a grin, but instead of what I wanted I found a serious and somewhat circular argument that literature should intervene in imperialist Western societies through an "indefatigable advocacy of the rights of the sans papiers" who are "trying to cross the Mexican border or to reach Europe on fast-sinking boats." Lecercle also argues against "the George W. Bush parenthesis" and its "blatant imperialist aggression" (917).

In Philosophy of Nonsense, Lecercle argued that "discourse is always the product of a dialogue, or a clash, between institutions" (179). In "Return to the Political," he writes off the Bush administration and the human rights gains it secured for Afghan women. Nine million women in Afghanistan can read thanks to the Bush administration. As people stream out of the Third World, Lecercle argues that we must fight for their rights. But only here. Why not there? Human rights are either universal or nonexistent. If a whole gender is subjected to silence, how can it participate in "discourse"?

Meanwhile, Lecercle raises the question of the silencing of Marxism in the New Criticism. But was Marxism silenced, or was it delegitimized because it silenced freedom of thought? In the Soviet Union, Andrey Zhdanov imprisoned humorists and reduced writing to praise of Stalinist policy. Similar censorship was imposed throughout the Eastern Bloc and Mao's China and resulted in the destruction of literacy itself by the Khmer Rouge. North Korea is a reminder that totalitarian intervention against freedom of inquiry continues. Do we want only political institutions to remain standing? Is Lecercle kidding?

Shall we reduce writing to the critique of whatever egg happens to be rolling across the White House lawn? Thumbs up if it's a Democrat, thumbs down if it's a Republican? In Philosophy of Nonsense, Lecercle reminded us that any judgment is often hilarious: "the vast number of trial scenes in nonsense has often been noted by critics" (71).

The Soviet Union became a laughingstock partially because of its criminally complacent approach to the law (show trials, no trials, and trial by disappearance). The state was the only standing institution, and no one was permitted to question its edicts. To return to a state where the political trumps all else is Lecercle's rallying cry-and yet he denies that it is: "Much as I 